\title{
Wife Left Home
}

National Cancer Institute

\section{Source}

National Cancer Institute. Wife Left Home. NCI Thesaurus. Code C150732.

An indication that a female, married individual who is or was living with another person left their shared home. 